\title{
New Regionalism in the UK: eliminating spatial disparities in unemployment?
}

\begin{abstract}
Regional employment policies in the UK can be classified as conforming to the new regionalism paradigm with a 'Third Way' concern for social inclusion. In place of the Keynesian welfare state policy of full employment the government favours development of clusters and promotion of social entrepreneurship as the engines of economic growth, stimulus for labour demand, developing the 'employability' of workless groups and as a means of addressing social exclusion. This paper scrutinises the viability of this programme as a means of eliminating spatial disparities in unemployment and finds that it is incapable of achieving this objective in an environment of macroeconomic constraint.
\end{abstract}

\section{Introduction}

Over the past three decades unemployment in the UK has persisted at levels not experienced in the previous postwar period and significant regional variations have emerged. Fundamental economic changes provided the impetus for the introduction of neo-liberal policies that transformed the mixed economy of welfare and ruled out a spatial Keynesianism approach to regional development. In recent years a range of strategies and institutional arrangements have been implemented which highlight the importance of regional and local economic development and fit broadly under the rubric of 'new regionalism' (NR). This paper examines regional policies in the UK with particular reference to employment effects. The next section describes the abrogation of government responsibility for the provision of welfare that was central to the postwar welfare state in favour of market dominance and supply-side remedies for unemployment. Section 3 defines the broad characteristics of NR including the role of clusters, social entrepreneurship and local partnerships. This is followed by a discussion of EU regional policies in the context of the European Employment Strategy. Section 5 outlines regional policy initiatives in the UK and the final section assesses the viability of existing regional policy to eliminate regional variations in employment and unemployment.

\section{Transformation of the welfare state}

The 1970s economic crisis laid the basis for the shift to neo-liberal economic policies (see, for instance, Gough, 1979; Mishra, 1990; Cook, 2007) that included the abandonment of the commitment to full employment, the embrace of globalisation, opening up profit-making opportunities in sectors that were previously outside the ambit of the market, and restricting deductions from surplus value that were channelled into the welfare state.

The OECD Jobs Study (OECD, 1994) elaborated a program of restrictive macroeconomic policies that focussed on: inflation targeting and reducing budget deficits and government debt; labour market flexibility with regard to employment security, working time, wage and other labour costs; 'activation' of the economically inactive; and improving conditions for business through reduced regulation and fostering technological advances. In particular, labour market 
flexibility was to be achieved by maximising participation to reduce wage pressures, and included fundamental attacks on the right to welfare through increasingly onerous conditionality for the unemployed, and subsequently, other workless groups such as lone parents and people with disabilities. Part-time employment was encouraged, while institutional and regulatory changes eliminated some long-standing working conditions and made work more precarious.

The European Employment Strategy (EES), initiated at the Luxembourg Summit in 1997, consisted of four pillars; employability, entrepreneurship, adaptability and equal employment opportunity (Employment and Social Affairs, 2004). These objectives were extended at the Lisbon summit in 2000 to include full employment in Europe by 2010, improved quality and productivity of work, and social cohesion and inclusion. The strategy's economic pillar aimed to boost competitiveness, adaptability and dynamism in the economy and invest in research and development. Full employment has been redefined as an employment rate of 70 per cent of the working age population. Social policy focussed on social inclusion, which is increasingly equated with labour force participation. Scharpf (2002) points to the schism between EU economic and social policy declaring that the 'employability' pillar means increasing the skills and work incentives of the unemployed, 'entrepreneurship' means removing regulatory and other barriers faced by business, and 'adaptability' means reducing employment protection.

In 2005 the relaunched strategy aimed at "delivering stronger, lasting growth and creating more and better jobs" (Commission of the European Communities, 2005c: 7) through a business-led strategy similar to that advocated by the OECD. Specific objectives comprised reducing government debt, pension and health system reform and switching public expenditure to growth enhancing categories. In addition to ensuring open and competitive markets various measures to support business were proposed such as encouraging research and innovation networks, and reducing regulation (Commission of the European Communities, 2005a; 2005c; 2007). Declaring that "[e]mployment policies can make a decisive contribution to raising employment and productivity growth, and to strengthening social cohesion" (Commission of the European Communities, 2005a: 9), the strategy proposed that unemployment could be reduced by combining wage moderation with rising participation, active labour market policies, greater commitment to training, and increased work incentives through tax and benefit system reforms (Commission of the European Communities, 2005c).

While classification of this agenda as neo-liberal has been contested (Annesley, 2007) both the EU and OECD policies constitute welfare state retrenchment because they transfer resources from labour to capital and privilege market provision of services. Table 1 highlights the characteristics of the transformed welfare state, variously referred to as the post-welfare state (Jamrozik, 2005), the Enabling State (Gilbert and Gilbert, 1989), the Schumpeterian workfare post-national regime (Jessop, 1999; 2004), or the Full Employability Framework (Allen et al., 2007; Mitchell and Muysken, 2008). Importantly, it demonstrates the retreat from government acceptance of responsibility for welfare. Restrictive fiscal policies and inflation targeting reflect the abandonment of full employment in favour of international competitiveness and supply-side 'Schumpeterian' policies to promote innovation and strengthen competitiveness (Jessop, 1999; 2004). The focus of redistributive policies is to stimulate market outcomes through privatisation and conditionality of access to welfare state services (Jamrozik, 2005; Allen et al., 2007; Mitchell and Muysken, 2008). The diminution of access to the welfare state as a right of citizenship is emphasised by the rhetoric applied to the unemployed and other 'workless' groups of working age; 'mutual obligation', 'rights and responsibilities', 'right and duty' in an environment of insufficient labour demand. 
Table 1: Comparison of the welfare state and the post welfare state

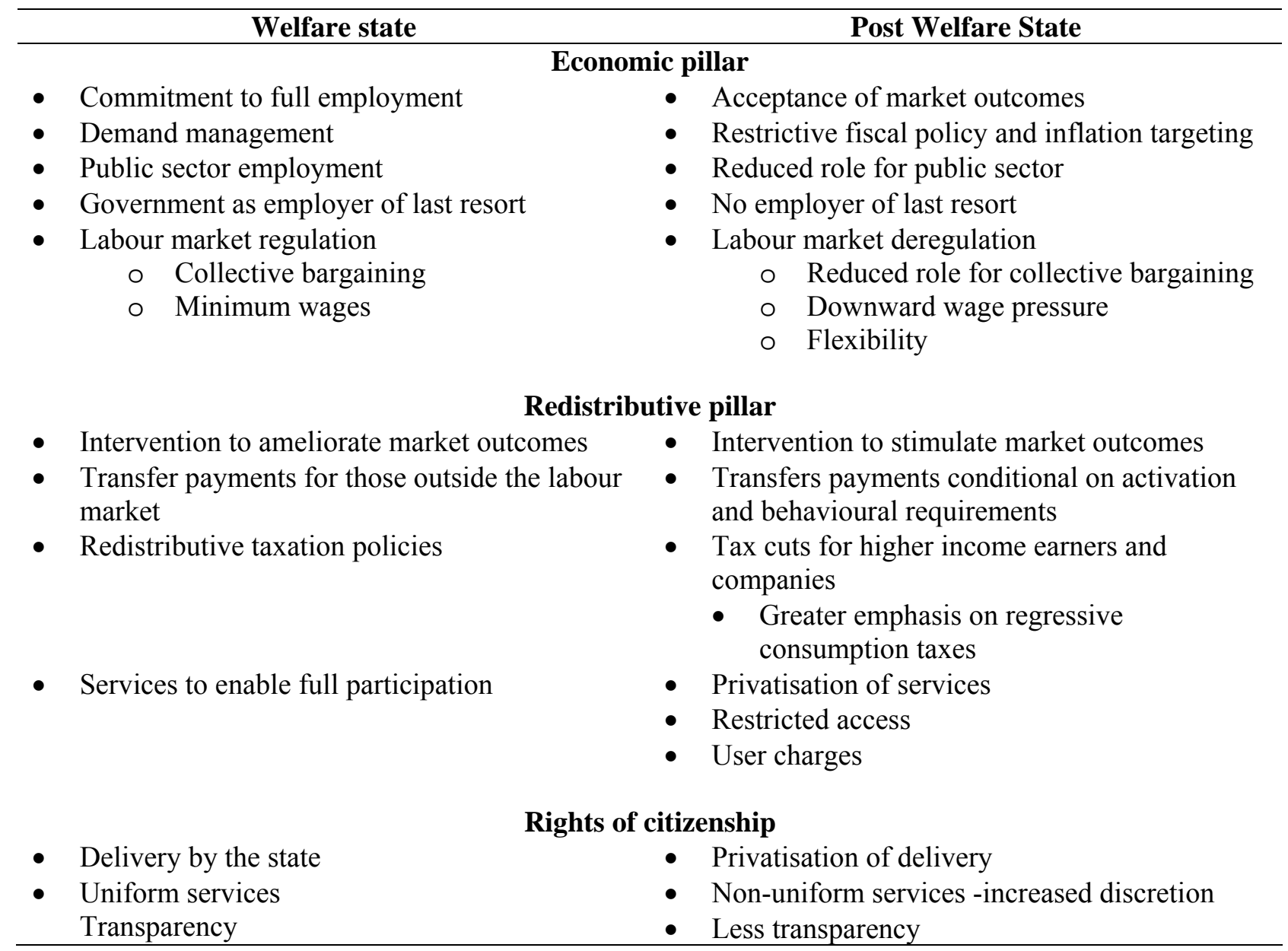

Sources: Derived from (Jamrozik, 2005; Cook, 2006; Allen et al., 2007; Mitchell and Muysken, 2008)

According to Jessop $(1999 ; 2004)$ the advent of globalisation has fundamentally changed or 'hollowed out' the role of the state. He claims that the regulatory control of nation states has diminished and state facilitation of the accumulation process has changed. Under the welfare state national capital was geographically tied to the nation and relied on the availability of a healthy, educated workforce (Teeple, 1995). However, unfettered capital flows after the demise of the Bretton Woods financial arrangements meant that production could be shifted to areas offering lower labour, infrastructure or regulatory costs. Jessop points to the transfer of some nation-state responsibilities to supra-national organisations such as the EU, while other functions have been devolved to sub-national spheres such as regional levels. In this new scenario, the state focuses on the attraction and retention of mobile international capital and increasing international competitiveness at the expense of coordinated policies to promote balanced growth and ensure full employment.

\section{What is New Regionalism?}

There is no agreed definition of NR (Haughton and Counsell, 2004; Rainnie and Grant, 2004). NR recognises that aggregate economic activity is an insufficient condition to eliminate regional economic differentials and posits that coordinated regional policies pursued through a variety of institutional and funding arrangements are essential to promote balanced growth. Within the NR literature concepts such as clusters, networks, local partnerships, the knowledge economy, cooperatives, social entrepreneurship and social inclusion are prominent and intertwined.

\section{Clusters}

In the forefront of the NR phenomenon is the proposal that industry clusters drive economic and employment growth through a dynamic process of competitiveness, productivity and innovation. Competitiveness is determined by the degree of development and intensity of interaction of the 
four components of Porter's (1998a; 1998b) 'diamond of competitiveness' - firm strategy and rivalry, demand conditions, related and supporting industries, and factor conditions - and is enhanced when firms are clustered to include a range of industries that are important to competition including suppliers of raw materials, capital equipment, financial and business services, educational and research institutions. The two core elements of clusters are geographical proximity and linkages between firms (Martin and Sunley, 2003; Malmberg and Power, 2006; Simmie, 2006).

Martin and Sunley (2003) summarise the proposed benefits of clusters; that they increase productivity, innovation, competitiveness, profitability and job creation of participating firms, regions and the national economy. Enhanced innovation is achieved through active participation in networks involving mutual understanding, trust and openness (Belussi, 2006; Nooteboom, 2006), interactive learning through direct observation of competitors and exploitation of collective knowledge (Lorenzen and Maskell, 2004; Bell, 2005; Malmberg and Power, 2006), and diffusion of leading-edge knowledge, products and services due to international spillovers from sophisticated customers (Simmie, 2006).

Agglomeration advantages include: development of a specialised labour force to enhance labour market efficiency; local provision of specialised supplies of raw materials and intermediate goods; maximisation of information flows (Gordon and McCann, 2000); and access to transport, other infrastructure and markets (Arnould and Mohr, 2005; Belussi, 2006). Institutional embeddedness is also important, including regional characteristics such as regulation and norms of conduct, taxes, subsidies, legal systems, infrastructure, education, research and the labour market.

The major negative consequences of successful clusters are congestion, escalating prices for land, labour and services (Martin and Sunley, 2003; Henry, Pollard and Benneworth, 2006; Maskell and Kebir, 2006; Swann, 2006), and negative distributional consequences since certain individuals or industries within the area as well as rural and regional areas may be excluded from the benefits (Asheim, Cooke and Martin, 2006; Henry, Pollard and Benneworth, 2006; Swann, 2006). In addition, clusters may be adversely affected by external shocks such as changes in technology or consumer preferences, especially clusters with a high concentration of similar firms (Rosenfeld, 1997; Martin and Sunley, 2003; Maskell and Kebir, 2006).

\section{Social Entrepreneurship}

Social entrepreneurship has been promoted as a means of addressing regional disadvantage (Latham, 2001; DTI, 2002: 7) but has also been widely criticised as a fundamentally flawed strategy (see Cook, Dodds and Mitchell, 2003). Social entrepreneurship includes a conglomeration of activities by innovative organisations (Austin, 2006; Perrini and Vurro, 2006; Mair and Naboa, 2006) using business techniques to attain social goals (Haugh, 2006; Latham 2001: 23). A social enterprise has been defined as:

a business with primarily social objectives whose surpluses are principally reinvested for that purpose in the business or in the community, rather than being driven by the need to maximise profit for shareholders and owners (DTI, 2002: 7)

While there is no consensus in the literature, social entrepreneurship is frequently conceptualised as finding practical solutions to social problems, including both non-profits and for-profit entities that pursue double- or triple-bottom line outcomes (Dees, 2001; Thompson, 2002; Eikenberry and Kluver, 2004; Roper and Cheney, 2005; Martin and Osberg, 2007). Public sector activities and cross-sector partnerships that include business, government agencies and community organisations have also been classified as social entrepreneurship (Roper and Cheney, 2005; Austin, 2006).

Wallace (1999) includes community businesses, co-operatives, community development trusts, local credit unions, community-based housing associations and community development corporations in the list of social enterprises. In Alter's (2006) typology of social entrepreneurship 
the 'employment' model is designed to create employment opportunities for the target group, usually disadvantaged job seekers such as people with disabilities, ex-offenders, or youth at risk. The enterprise may operate services such as landscaping and cleaning or businesses such as cafes, bakeries, book shops or used clothing shops. Often they provide support services to employees including counselling, training and living skills. The 'fee-for-service' model involves provision of social services such as education or health to the target population, communities or to a third party payer.

\section{Regional policy in the European Union}

EU regional policy is premised on reducing disparities in economic growth and labour market access as the way to address social exclusion, reduce bottlenecks and inflationary pressures and maintain social cohesion (Commission of the European Communities, 2005b). Regional employment policy is implemented through the European Employment Strategy (EES) and nationally based policies. A local dimension was added to the EES in 2001 and National Action Plans from member countries outlined national, regional and local policies to support job creation (Employment and Social Affairs, 2004). The relaunched Lisbon strategy re-iterated the objective of reducing regional disparities in employment and unemployment rates by ensuring that regional and national employment programmes targeted less prosperous regions (Commission of the European Communities, 2005c).

Delivery of the EES is underpinned by the Structural Funds that support regional programmes to combat unemployment and develop human resources to ensure a high level of employment. For the period 2000-06 there were three major priorities for the Structural Funds (European Commission, 2004). Objective 1 funding promoted development and structural adjustment for lagging regions (regions with per capita GDP less than 75 per cent of the Community average). Financial support for infrastructure, investment, human resource development, and industry restructuring was provided to enhance productivity and competitiveness of the designated regions, and ultimately produce convergence. Objective 2 supported areas experiencing structural difficulties in industrial or service sectors, declining rural areas, depressed urban areas or areas reliant on fisheries. Modernisation of education and training, along with labour market integration of youth, the long-term unemployed and those at risk of exclusion, constituted Objective 3.

From 2007 the Structural Funds came under the reformed Cohesion Policy that focuses on knowledge and the information society, entrepreneurship, the environment and employment (EC, 2006). The bulk of the funding is available to the poorest or 'Convergence' regions while 'Regional Competitiveness and Employment' funding will: assist innovation and knowledge transfer; stimulate enterprise by promoting business clusters assisting with finance and incubators; promote social entrepreneurship, employment and public services; regenerate deprived neighbourhoods; and contribute to sustainable development, and improve accessibility to training projects (Third Sector European Network, 2007)

\section{Regional and local policies in the UK}

The UK supply-side approach to unemployment has been supplemented in recent years with a Third Way concern for solving social exclusion. Policies are generally implemented and tightly controlled at the national level with the centrepiece being various New Deal programmes to enhance employability. The government set the objective of full employment in every region (defined as an employment rate of 80 per cent) and stated that "the best way to overcome regional disparities is to allow each nation, region and locality the freedom and flexibility to exploit their indigenous sources of growth" (DTI, 2006: 10). Regional economic polices are funded predominantly by the national government, complemented with EU funding, and focus on the Lisbon objectives of increasing growth and productivity (HM Treasury, 2005). In addition, as part of the Third Way philosophy, there is a focus on addressing social exclusion through localised interventions in deprived communities that incorporate partnerships between the public, private and voluntary sectors (Bradford, 2005; McCabe and Hahn, 2006). 
Regional policies in the UK include encouragement of cluster development, social enterprise, local strategies, and local variations on national labour market policies designed to 'activate' the unemployed and enhance employability. Regional economic strategies are the responsibility of Regional Development Agencies (RDAs) that were established in 1999 and are composed of representatives from local government, the voluntary sector, trade unions and local business. RDAs are responsible for regional economic development, industry and employment generation and skill development. RDAs are funded by six government departments with total funding of $£ 2,309$ million for 2007-08 (OECD, 2007).

\section{Cluster promotion by Regional Development Authorities}

Following the 1998 Competitiveness White Paper the government set out to identify barriers to clusters declaring that clusters have a key role in economic development in regional and local economies (DTI, 2004; OECD, 2007). In A Practical Guide to Cluster Development the critical success factors identified were: networks and partnerships; strong skills base; innovation and R\&D capacity; presence of large firms; adequate infrastructure; entrepreneurial spirit; and access to finance (DTI, 2004).

RDAs encourage cluster development rather than attempting to artificially create them (OECD, 2007). The Cluster Liaison Group initiates activities that may involve several RDAs. For example Motorsport Development UK involves four RDAs. The private-led Technology Strategy Board established in 2004, plays a leading role in identifying areas for investment. The Board oversees Collaborative Research partnerships between research institutions and industry, and Knowledge Transfer Networks consisting of partnerships between business, universities, research and technology organisations, and financial institutions to facilitate knowledge transfer. Regional clusters are encouraged to participate in Knowledge Transfer Networks. Some clusters identified by RDAs (England's Regional Development Agencies, 2007), include:.

- West Midlands - Building technologies, Food and drink, Tourism and leisure, and High value-added consumer products

- Yorkshire - Digital industries, Advanced engineering and metals, Food and drink, Environmental technologies, and Healthcare

- South West - Bio-medical, Semi-conductor design, and Digital media

- South East - Renewable and other low carbon energy technologies

- North West - Biomedical, Energy and environmental technologies, Advanced engineering and materials, Food and drink, Digital and creative industries, and Business and professional services

- East of England - Cambridge Knowledge-Based Cluster

- North East England - North East Process Industry Cluster (NEPIC), Nuclear energy, Renewable energy and environment, and Oil and gas

- East Midlands, West Midlands, East of England, and South East - Motorsport Development UK

\section{Social entrepreneurship}

As part of the restructuring of the welfare state, the UK government encourages social enterprises to participate in provision of government services and to play a leading role in regeneration of deprived communities (McCabe and Hahn, 2006). The Government's social enterprise strategy, Social enterprise: A strategy for success, was released in 2002 to promote social enterprise and improve business performance of social enterprise (DTI, 2002). The strategy is implemented by RDAs and Government Offices in partnership with local authorities, the Co-operative Movement, and the social enterprise sector. In order to achieve the objectives of identifying markets and removing barriers to operation of social enterprises (Office of the Third Sector, 2006), the Social Enterprise Network was established and RDAs developed social enterprise plans or integrated social enterprise objectives into the Regional Economic Strategy. Specific initiatives have included financial training for social enterprises, encouraging 
relationships with other businesses, encouraging firms to form partnerships with social enterprises to deliver 'corporate social responsibility objectives', replicating best practice in social enterprise, and facilitating the growth of social enterprise clusters (Office of the Third Sector, 2006: 67).

The Government established the Office of the Third Sector in 2006 and will provide £515 million between 2008 and 2011 for third sector programmes. Social enterprises are promoted as an alternative to the private sector for provision of contracted public services that were previously delivered by the public sector. For example, the Social Enterprise Unit in the Department of Health actively promotes delivery of health and social services by social enterprises. In relation to employment services, social entrepreneurs deliver some New Deal and Pathways to Work services, around half WORKSTEP services, and almost all Work Preparation services (Office of the Third Sector, 2007).

Social entrepreneurship is seen as critical to delivery of local employment and development strategies and as a vehicle to tackle social problems in deprived communities. They are charged with increasing employability and removing barriers to employment by addressing child care and transport needs as well as negative employer attitudes towards the most disadvantaged (Department for Communities and Local Government, 2007b). One third of social enterprises in urban areas are located in the 20 per cent most deprived wards (Office of the Third Sector, 2006). The government has also emphasised the need for social enterprises in rural areas to generate employment, provide services that would otherwise not be provided, and tackle social exclusion.

\section{Area-based employment strategies}

Area-based policies, implemented to attack unemployment and social exclusion in deprived neighbourhoods, recognise that the benefits of general economic expansion are not equally shared, and involve local partnerships that including the public, private and voluntary sectors. As the Department for Communities and Local Government (2007b: 10) commented:

Worklessness cannot be holistically tackled at any one spatial level; whilst a strategic approach is needed at the level at which demand side failures in the labour market operate, it is equally true that local interventions are needed to ensure that emergent benefits are realised in deprived neighbourhoods.

The National Strategy for Neighbourhood Renewal commenced in 2001 to address multiple deficiencies and improve economic and social outcomes for the 88 deprived local authority districts in an attempt to reduce spatial disparities with the rest of the country. In addition to reducing worklessness, the objectives included improvements in health, skills, housing and the physical environment (Social Exclusion Unit, 2001). The strategy uses a place management approach through Local Strategic Partnerships (LSPs) to coordinate service delivery from various government departments (DWP, 2003).

New Deal for Communities (NDCs) commenced in 1998 to narrrow gaps between 39 deprived localities and the rest of the country in relation to education, crime, employment, health and housing. NDCs became part of the National Strategy for Neighbourhood Renewal and involve Job Centre Plus and other agencies collaborating to provide job mentoring and training, and Intermediate Labour Markets opportunities. Surveys of residents of New Deal for Communities areas found that the most successful method of job search was word of mouth and less than 10 per cent of those working, or who had previously worked, found jobs through Jobcentre Plus. These findings suggest that "where there are concentrations of unemployment, either spatially or in particular communities (for example asylum seekers), jobseekers are unlikely to have the connections to those in work needed to benefit from informal recruitment methods" (Department for Communities and Local Government, 2007b: 42). For this reason many partnerships have involved intermediaries to improve links between workless populations and the labour market.

As part of the Lisbon Strategy National Reform Programme report for 2006 the government outlined improved targeting of interventions to tackle deprivation. Rather than targeting the 30 
most deprived local authority areas the focus shifted to 903 individual wards (HM Treasury, 2006). An additional 13 Cities Strategy pathfinders consisting of government agencies, local government, the private and voluntary sectors will pool resources and expertise "in order to tackle unemployment in the areas furthest away from the 80 per cent employment rate ambition" (HM Treasury, 2006: 46). The Local Enterprise Growth Initiative (LEGI) also provides funds to deprived areas to support proposals to stimulate economic activity and enterprise (HM Treasury, 2006).

While Jobcentre Plus implements national employment policies such as the New Deal a number of local initiatives have attempted to improve outcomes in deprived areas or for specific client groups. Employment Zones were initiated in 15 deprived areas with high unemployment rates in 2000 in an area-based strategy to improve employment outcomes for long-term unemployed people aged 25 or older. The target group was expanded to include young people who would otherwise have returned to New Deal for Young People and sole parents who participated on a voluntary basis. Providers were afforded considerable flexibility in provision of intensive assistance and received financial incentives in a work-first approach that focussed on placing clients in employment as soon as possible. The rationale was that "payment by results, minimum regulation, operational and financial flexibilities, provider competition and customer choice were, over time, intended to drive through improvements in performance and service delivery and act as a benchmark for comparing their performance with mainstream employment services" (Griffiths and Durkin, 2007: 2).

The job creation StepUP pilot that ran from 2002 to 2004 represented another place-based attempt to address unemployment and labour market disadvantage. Jobseekers were placed in public, private or non-profit sector positions lasting 50 weeks. Managing agents located vacancies and support workers provided post placement support. The focus of the first half of the placement was maintaining the job while the second half was devoted to job search, with financial incentives provided to both the managing agent and participant for placements prior to completion.

The link between deprivation and areas with high numbers of incapacity beneficiaries (HM Treasury, 2006) has been used as justification for programmes such as Pathways to Work which entails compulsory attendance at work-focussed interviews with Personal Advisors and provides access to employment assistance. A major expansion of the programme in 2005-2006 concentrated on the most disadvantaged areas with the highest concentration of people on incapacity benefit, and the Green Paper, In Work, Better off: next steps to full employment proposes to make it a national programme by April 2008 with delivery primarily through the private and voluntary sectors (DWP, 2007).

\section{Discussion and Conclusions}

How have the UK regional policies impacted on the spatial distribution of employment opportunities and unemployment? Despite 56 quarters of uninterrupted economic growth (HM Treasury, 2006), Table 2 demonstrates that substantial variation in unemployment rates persists, with regional unemployment rates in 2007 ranging from a low of 3.6 per cent in Northern Ireland to almost double that in London (7.1 per cent). Similarly, changes in unemployment over the past several years display volatility and markedly different outcomes between regions. For example in 2006-07 unemployment increased by over 21 per cent in West Midlands but fell by almost 15 per cent in Scotland.

However, intra-regional variations in labour market experience are even more important, as the Department for Communities and Local Government (2007b: 5) notes:

Despite the overall increase in employment in recent years, spatial disparities locally have continued to grow: once upon a time, there were major regional differences in levels of unemployment; there are now differences within regions, in every region of the country" 
In 2006 London had the largest intra-regional variation with unemployment rates of 14.2 per cent in Tower Hamlets compared to 4.1 per cent in Richmond-upon-Thames (National Statistics, 2006). The lowest unemployment rate was in Eden, Cumbria (2.1 per cent) and the highest rate outside London was in South Tyneside (10.2 per cent).

Table 2: Regional unemployment rates and annual changes in unemployment,

\begin{tabular}{lrr|rrrrrr}
\hline & \multicolumn{2}{c|}{ UR } & \multicolumn{6}{c}{ Change in unemployment } \\
\hline UK & 2001 & 2007 & $2001-02$ & $2002-03$ & $2003-04$ & $2004-05$ & $2005-06$ & $2006-07$ \\
England & 4.9 & 5.3 & 3.38 & -3.54 & -1.91 & 0.29 & 18.16 & -1.88 \\
North East & 4.7 & 5.4 & 4.72 & -1.17 & -3.80 & 1.05 & 20.70 & 0.00 \\
North West & 7.6 & 6.3 & -14.77 & -8.00 & 7.25 & 28.13 & -8.54 & 5.33 \\
Yorkshire and Humber & 5.1 & 5.6 & 4.88 & -9.30 & -10.90 & -0.72 & 22.46 & 11.24 \\
East Midlands & 5.4 & 5.5 & -1.56 & -3.97 & -8.26 & 5.41 & 23.08 & -4.17 \\
West Midlands & 5.0 & 5.0 & -7.69 & -4.17 & -1.09 & 2.20 & 31.18 & -10.66 \\
East & 5.4 & 6.6 & 4.38 & -2.10 & -2.14 & -16.06 & 26.96 & 21.23 \\
London & 3.5 & 4.6 & 2.08 & 7.14 & 0.00 & 3.81 & 31.19 & -7.69 \\
South East & 5.8 & 7.1 & 11.01 & 5.79 & -2.34 & 2.80 & 15.56 & -4.04 \\
South West & 3.0 & 4.1 & 23.62 & 2.55 & -6.83 & 5.33 & 25.32 & -10.61 \\
Wales & 3.4 & 3.9 & 6.02 & -5.68 & 9.64 & 12.09 & 18.75 & 7.37 \\
Scotland & 5.8 & 5.6 & -5.26 & -16.67 & -5.00 & 8.77 & 29.03 & 0.00 \\
Northern Ireland & 6.3 & 4.7 & 1.91 & -15.00 & 16.18 & -7.59 & 0.68 & -14.97 \\
Soure: Nitan & 6.0 & 3.6 & -8.89 & -4.88 & -5.13 & 0.00 & -10.81 & -12.12 \\
\hline
\end{tabular}

Source: National Statistics (2007), Labour Force Survey.

Porter's contention that clusters are responsible for increased productivity and economic growth has resulted in promotion of clusters as a vehicle for economic development that is appropriate to all regions. The causal link between clusters and productivity growth has not been conclusively proven. Even if the benefits could be demonstrated, transplanting strategies used by successful clusters is far from straightforward precisely because these clusters are the product of unique and spatially specific conditions including resources, dynamic networks and inter-firm relationships (Amin, 1999; Simmie, 2006; Swann, 2006). Some authors contend that clusters have been oversold and should be considered as 'a' policy rather than 'the' policy (Martin and Sunley, 2003; Henry, Pollard and Benneworth, 2006). Used in isolation policies to promote clusters are unlikely to have a significant impact on unemployment, especially in disadvantaged areas.

The promotion of social enterprise is closely linked to government abrogation of responsibility for full employment and the desire to outsource services previously delivered by the public sector. While social enterprise is eulogised as a solution to unemployment, particularly in deprived neighbourhoods, McCabe and Hahn (2006: 396) point out that "there is a gap between the rhetoric attached to social enterprise and its capacity to deliver economic and social policy imperatives" and conclude that it has only a marginal impact at the macro level and is highly reliant on government support. A survey of social enterprise in the UK in 2005 found that there were around 15,000 social enterprises with total employment of only 475,000 (IFF Research Ltd, 2005).

Evaluations of the plethora of programmes implemented to solve localised unemployment and address social exclusion demonstrate the inadequacy of such programmes and stress that positive benefits may take several years to materialise (Department for Communities and Local Government, 2007a). In NDC areas unemployment fell by 3 per cent compared to the national average of 1 per cent between 1995 and 2005, however worklessness increased due to the rise in incapacity benefit claimants (Beatty et al., 2007; Department for Communities and Local Government, 2007a). Between 2002 and 2006 the employment rate remained stable at 52 per cent in NDC areas, far short of the national rate of 75 per cent. Employment outcomes for StepUP participants were better than for the control group but varied by age group. Significantly, higher employment outcomes were achieved by disadvantaged groups. Superior employment outcomes in Employment Zones evaporated over time (Griffiths and Durkin, 2007). Many 
participants of both Employment Zones and the New Deal have churned through multiple stints on the programmes without achieving sustainable employment outcomes.

A further concern is the fact that even where local programmes are successful in expanding employment opportunities there is no guarantee that local residents will be employed since positions are often filled by persons commuting from other areas (North et al., 2003; Department for Communities and Local Government, 2007b). Of particular concern is the fact that, far from improvements in the spatial dispersion of unemployment, it is becoming more concentrated for particular neighbourhoods and employment outcomes have not improved for the most disadvantaged jobseekers (Commission of the European Communities, 2004; Scottish Executive, 2006; Department for Communities and Local Government, 2007b). In short, programmes targeting deprived areas may result in improved amenity through housing renewal, reduced crime and perceptions of increased safety but they have not impacted significant on employment outcomes and are incapable of eliminating spatial disparities in employment and unemployment rates or disadvantage.

Most importantly, NR ignores the critical importance of aggregate demand in stimulating regional economic and employment growth and conforms to supply-side prescriptions emanating from neo-liberal economic policy (Gray, Crofts and Healy, 2001). While regional policies have produced some positive results the interventions have occurred in a constrained macroeconomic environment and are of insufficient scale to address persistent unemployment. As Mitchell and Juniper (2005: 20) point out, "it is a compositional fallacy to assume that all regions can lift themselves without a buoyant aggregate climate." A return to full employment depends on utilisation of fiscal and monetary policy to ensure a high level of aggregate demand and spatially specific employment creation at a scale sufficient to ensure employment for all those seeking work.

\section{References}

Allen, E., Cook, B., Mitchell, W. and Watts, M. (2007) 'The failed full employability paradigm', Working Paper No. 07-04, Centre of Full Employment and Equity, University of Newcastle.

Alter, K. (2006) Social Enterprise Typology, Accessed 21 March 2007, Available at: http://www.virtueventures.com/setypology.pdf.

Amin, A. (1999) 'An Institutionalist perspective on Regional Economic Development', International Journal of Urban and Regional Research, Vol. 23, Issue 2, pp.365-378.

Annesley, C. (2007) 'Lisbon and social Europe: towards a European 'adult worker model' welfare system', Journal of European Social Policy, 17, pp.195-205.

Arnould, E. J. and Mohr, J. J. (2005) 'Dynamic Transformations for Base-of-Pyramid Market Clusters', Academy of Marketing Science Journal, 33, 3, Summer, pp.254-274.

Asheim, B., Cooke, P. and Martin, R. (2006) 'The rise of the cluster concept in regional analysis and policy: A critical assessment', In B. Asheim, P. Cooke \& R. Martin (Eds.), Clusters and Regional Development: Critical reflections and explorations, Routledge, London, pp. 1-29.

Austin, J. E. (2006) 'Three Avenues for Social Entrepreneurship Research', In J. Mair, J. Robinson \& K. Hockets (Eds.), Social Entrepreneurship, Palgrave Macmillan, Basingstoke, pp. 22-33.

Beatty, C., Foden, M., Lawless, P. and Wilson, I. (2007) New Deal for Communities National Evaluation: An Overview of Change Data: 2006, Research Report 33 Department for Communities and Local Government, London.

Bell, G. (2005) 'Clusters, Networks, and Firm Innovativeness', Strategic Management Journal, 26, pp.287-295.

Belussi, F. (2006) 'In search of a useful theory of spatial clustering: Agglomeration versus active clustering', In B. Asheim, P. Cooke \& R. Martin (Eds.), Clusters and Regional Development: Critical reflections and explorations, Routledge, London, pp. 69-89. 
Bradford, N. (2005) Place-based Public Policy: Towards a New Urban and Community Agenda for Canada, Research Report F/51, Family Network, Canadian Policy Research Networks, Ottawa.

Commission of the European Communities (2004) Strengthening the implementation of the European Employment Strategy, COM (2004) 239 final.

Commission of the European Communities (2005a) Integrated Guidelines for Growth and Jobs: 2005-2008, COM(2005) 141 final.

Commission of the European Communities (2005b) Lisbon Action Plan Incorporating EU Lisbon Programme and Recommendations for Actions to Member States for Inclusion in their National Lisbon Programmes, SEC (2005) 192.

Commission of the European Communities (2005c) Working together for growth and jobs: A new start for the Lisbon Strategy, COM(2005)24.

Commission of the European Communities (2007) The European Interest: Succeeding in the age of globalisation, $\operatorname{COM}(2007) 581$ final.

Cook, B. (2006) 'Conceptual framework for analysis of welfare state developments', Working Paper No. 06-06, Centre of Full Employment and Equity, University of Newcastle.

Cook, B. (2007) Whither the welfare state? Australian and international welfare state developments since 1975, PhD Thesis, University of Newcastle, Newcastle.

Cook, B., Dodds, C. and Mitchell, W. (2003) 'Social entrepreneurship - false premises and dangerous forebodings', Australian Journal of Social Issues, Volume 38, Number 1, pp.57-72.

Dees, J. G. (2001) The Meaning of "Social Entrepreneurship", Accessed 12 March 2007, Available at: http://www.fuqua.duke.edu/centers/case/documents/dees sedef.pdf.

Department for Communities and Local Government (2007a) New Deal for Communities National Evaluation: An Overview of Change Data: 2006, Research Report 33, Department for Communities and Local Government, London.

Department for Communities and Local Government (2007b) What works in economic development for deprived neighbourhoods?, Department for Communities and Local Government, London.

Department for Work and Pensions (DWP) (2003) UK National Action Plan on Social Inclusion 2003-05, Department of Work and Pensions.

Department for Work and Pensions (DWP) (2007) In work, better off: next steps to full employment, TSO, Norwich.

Department of Trade and Industry (DTI) (2002) Social Enterprise: a strategy for success, Department of Trade and Industry, London.

Department of Trade and Industry (DTI) (2004) A Practical Guide to Cluster Development, A Report to the Department of Trade and Industry and the English RDAs by Ecotec Research and Consulting, DTI Publications, London.

Department of Trade and Industry (DTI) (2006) United Kingdom: National Strategic Reference Framework, EU Structural Funds Programmes 2007-2013, Department of Trade and Industry.

Eikenberry, A. M. and Kluver, J. D. (2004) 'The Marketization of the Nonprofit Sector: Civil Society at Risk?' Public Administration Review, 64, 2, Mar/Apr 2006, pp.132-140.

Employment and Social Affairs (2004) More and better jobs for all: The European Employment Strategy, Office for Official Publications of the European Communities, Luxembourg.

England's Regional Development Agencies (2007) Increasing prosperity in England's regions by bringing good ideas to life, Accessed 30 September 2007, Available at: http://www.englandsrdas.com/home.aspx.

European Commission (2004) More and better jobs for all: The European Employment Strategy, Office for Official Publications of the European Communities, Luxembourg.

European Commission (EC) (2006) A reformed Cohesion Policy for a changing Europe: Regions, Cities and Border areas for Growth and Jobs, Inforegio factsheet, Accessed 10 May 2007, Available at: http://ec.europa.eu/regional_policy/index_en.htm. 
Gilbert, N. and Gilbert, B. (1989) The Enabling State: Modern Welfare Capitalism in America, Oxford University press, New York.

Gordon, I. R. and McCann, P. (2000) 'Industrial Clusters: Complexes, Agglomeration and/or Social Networks?' Urban Studies, Vol. 37, No. 3, pp.513-532.

Gough, I. (1979) The Political Economy of the Welfare State, Macmillan Press, London.

Gray, M., Crofts, P. and Healy, K. (2001) 'Social Entrepreneurship: Whose responsibility is it any way?' Paper presented at the Social Entrepreneurship Workshop: whose responsibility is it anyway?, Centre of Full Employment and Equity and the Department of Social Work, The University of Newcastle, 21 November 2001.

Griffiths, R. and Durkin, S. (2007) Synthesising the evidence on Employment Zones, DWP Research Report No 449, Department for Work and Pensions, Norwich.

Haughton, G. and Counsell, D. (2004) Regions, Spatial Strategies and Sustainable Development, Routledge, London.

Henry, N., Pollard, J. and Benneworth, P. (2006) 'Putting clusters in their place', In B. Asheim, P. Cooke \& R. Martin (Eds.), Clusters and Regional Development: Critical reflections and explorations, Routledge, London, pp. 272-291.

HM Treasury (2005) Lisbon Strategy for Jobs and Growth: UK National Reform Programme, HMSO, Norwich.

HM Treasury (2006) Lisbon Strategy for Jobs and Growth: UK National Reform Programme, HMSO, Norwich.

IFF Research Ltd (2005) A Survey of Social Enterprises Across the UK, Small Business Service.

Jamrozik, A. (2005) Social Policy in the Post-Welfare State: Australian society in the 21st century, (2nd edition), Pearson Education Australia, Frenchs Forest, NSW.

Jessop, B. (1999) Narrating the Future of the National Economy and the National State? Remarks On Remapping Regulation and Reinventing Governance, published by the Department of Sociology, Lancaster University, Lancaster LA1 4YN, at http://www.lancs.ac.uk/fss/sociology/papers/jessop-narrating-the-future.pdf.

Jessop, B. (2004) 'Hollowing out the 'nation-state' and multi-level governance', In P. Kennett (Ed.), A handbook of Comparative Social Policy, Edward Edgar Publishing Cheltenham,

Latham, M. (2001) 'The new economy and the new politics', In P. Botsman \& M. Latham (Eds.), The Enabling State: People before bureaucracy, Pluto Press, Annandale, pp. 13-35.

Lorenzen, M. and Maskell, P. (2004) 'The cluster as a nexus of knowledge creation', In P. Cooke \& A. Piccaluga (Eds.), Regional Economies as Knowledge Laboratories, Edward Elgar, Cheltenham, pp. 77-92.

Malmberg, A. and Power, D. (2006) 'True clusters: A severe case of conceptual headache', In B. Asheim, P. Cooke \& R. Martin (Eds.), Clusters and Regional Development: Critical reflections and explorations, Routledge, London, pp. 50-68.

Martin, R. and Sunley, P. (2003) 'Deconstructing clusters: chaotic concept or policy panacea?' Journal of Economic Geography, 3, pp.5-35.

Martin, R. L. and Osberg, S. (2007) 'Social Entrepreneurship: The Case for Definition', Stanford Social Innovation Review, Spring 2007.

Maskell, P. and Kebir, L. (2006) 'What qualifies as a cluster theory?' In B. Asheim, P. Cooke \& R. Martin (Eds.), Clusters and Regional Development: Critical reflections and explorations, Routledge, London, pp. 30-49.

McCabe, A. and Hahn, S. (2006) 'Promoting Social Enterprise in Korea and the UK: Community Economic Development, Alternative Welfare Provision or a Means to Welfare to Work?' Social Policy \& Society, 5:3, pp.389-398.

Mishra, R. (1990) The Welfare State in Capitalist Society: Policies of Retrenchment and Maintenance in Europe, North America and Australia, Harvester Wheatsheaf, Hemel Hempstead.

Mitchell, W. and Juniper, J. (2005) 'Towards a Spatial Keynesian macroeconomics', Working Paper 05-09, Centre of Full Employment and Equity, The University of Newcastle.

Mitchell, W. F. and Muysken, J. (2008) Full Employment abandoned: shifting sands and policy failures, Edward Elgar, Aldershot. 
National Statistics (2006) Annual Population Survey, Accessed 11 October 2007, Available at: https://www.nomisweb.co.uk/default.asp?Session_GUID $=\{313289$ C4-D064-4ABF9232-ABBC28A3FD67\}.

National Statistics (2007) Labour Force Survey, Accessed 26 October 2007, Available at: http://www.statistics.gov.uk.

Nooteboom, B. (2006) 'Innovation, learning and cluster dynamics', In B. Asheim, P. Cooke \& R. Martin (Eds.), Clusters and Regional Development: Critical reflections and explorations, Routledge, London, pp. 137-161.

North, D., Smallbone, D., Lyon, F. and Potts, G. (2003) Business-led regeneration of deprived areas: A review of the evidence base, Research Report 5 Office of the Prime Minister, Wetherby.

OECD (1994) Jobs Study, Organisation for Economic Co-operation and Development, Paris.

OECD (2007) Competitive Regional Clusters: National Policy Approaches, OECD, Paris.

Office of the Third Sector (2006) Social enterprise action plan: Scaling new heights, HM Government, London.

Office of the Third Sector (2007) Partnership in Public Services: An action plan for third sector involvement, HM Government, London.

Porter, M. E. (1998a) The Competitive Advantage of Nations, Palgrave, Basingstoke.

Porter, M. E. (1998b) On Competition, Harvard Business School Publishing, Boston.

Rainnie, A. and Grant, J. (2004) 'The Knowledge Economy, New Regionalism and the Reemergence of Regions', In A. Rainnie \& M. Grobbelaar (Eds.), New Regionalism in Australia, Ashgate, Burlington pp. 3-23.

Roper, J. and Cheney, G. (2005) 'Leadership, learning and human resource management: The meanings of social entrepreneurship today', Corporate Governance, 5, 3, pp.95-104.

Rosenfeld, S. A. (1997) 'Bringing Business Clusters into the Mainstream of Economic Development', European Planning Studies, Vol. 5, No. 1, pp.3-23.

Scharpf, F. W. (2002) 'The European Social Model: Coping with the Challenges of Diversity', Journal of Common Market Studies, Volume 40, Number 4, pp.645-670.

Scottish Executive (2006) Workforce Plus: an Employability Framework for Scotland, Scottish Executive, Edinburgh.

Simmie, J. (2006) 'Do clusters or innovation systems drive competitiveness?' In B. Asheim, P. Cooke \& R. Martin (Eds.), Clusters and Regional development: Critical reflections and explorations, Routledge, London, pp. 164-187.

Social Exclusion Unit (2001) A New Commitment to Neighbourhood Renewal: National Strategy Action Plan, Social Exclusion Unit, London.

Swann, G. M. P. (2006) 'Cluster and hinterland: when is a proactive cluster policy appropriate?' In B. Asheim, P. Cooke \& R. Martin (Eds.), Clusters and Regional Development: Critical reflections and explorations, Routledge, London, pp. 255-271.

Teeple, G. (1995) The Global Economy and the Decline of Social Reform, Humanities Press, Atlantic Highlands, New Jersey.

Third Sector European Network (2007) European Regional Development Fund Update, Accessed, Available at: http://www.tsen.org.uk/documents/EuropeanRegionalDevelopmentFundSummaryreport2 007-13.pdf

Thompson, J. (2002) 'The world of the social entrepreneur', The International Journal of Public Sector Management, 15, 1/5, pp.412-431.

Wallace, S. L. (1999) 'Social Entrepreneurship: The Role of Social Purpose Enterprises in Facilitating Community Economic Development', Journal of Developmental Entrepreneurship, 4, 2, Fall, pp.153-174. 